\title{
Research on the Formation Mechanism of the Competitive Advantage of the Enterprise Value Network
}

\author{
Du Wei \\ Hainan College of Software Technology, Qionghai, Hainan 571400 China \\ 1258502015@qq.com
}

Keywords: enterprise value, network competition advantage, formation mechanism

\begin{abstract}
With the acceleration of economic integration pace in the world, which makes research innovation points on value network emerge one after another, especially in the aspects of value creation of value network and research on competition advantage mechanism, although scholars have already made discussion on it from different perspectives. Research on value creation of value network and formation mechanism of competition advantage is favorable to explain causes why value network is becoming to be the new strategic model and enrich researches in this field. Based on this, this paper makes analysis on formation mechanism research of enterprise value network.
\end{abstract}

\section{Introduction}

Entering the $21^{\text {st }}$ century, with the acceleration of economic integration peace in the world, enterprise management becomes increasingly internationalized, customer demands are gradually increasing, which will inevitably bring about changes in value creation way. Enterprise value creation dose not depend on self effort from enterprises, but also depends on relations between upstream-and-downstream enterprise and customers, so value network theory emerges as times requires under this background, and it becomes to be the hot points in the research of strategic field by its unique value creation way. Scholars both in China and abroad have made research from different perspectives, but research on value creation of value network and formation mechanism of competition advantage is favorable to explain causes why value network is becoming to be the new strategic model and enrich research in this field. Based on this, this paper makes analysis on formation mechanism research of enterprise value network.

\section{Network evolution of enterprise value creation model}

\subsection{Effect of technological paradigm transfer on enterprise value network}

One of the conditions to transfer technological paradigm is appearance of natural limit of technology, which indicates technological marginal input in the technological paradigm transfer period is larger than that of marginal revenue. While technological marginal input is larger than marginal revenue, which indicates absolute of capital input elasticity in technology performance is less than 1. Suppose input function of technology performance is as follows:

$$
Z=a K^{b}
$$

In the formula, $\mathrm{Z}$ is technological performance, $\mathrm{K}$ is capital input; $\mathrm{a}$, $\mathrm{b}$ is constant. Performance elasticity of $\mathrm{K}$ is as follows:

$$
\begin{aligned}
\text { K performance elasticity } & =\text { performance change\% / capital change } \% \\
& =\frac{\Delta Z / Z}{\Delta K / K}=\frac{\Delta Z}{\Delta K} \cdot \frac{K}{Z}=\frac{\partial Z}{\partial K} \cdot \frac{K}{Z}=\left(a b K_{b-1}\right) \cdot \frac{K}{a K^{b}}=b
\end{aligned}
$$

Because elasticity lof $\mathrm{K}$ is less than 1 (capital input absolute value of technological performance is less than 1 ), so $b<1$, when $b<1$, relative to technological performance $Z$, capital input $K$ is 
decreasing in scale. That is to say, when marginal input of technology is larger than marginal revenue, technological performance is decreasing in scale. Therefore, enterprise value network may lose advantage of increasing in scale in the period of technological paradigm transfer.

\subsection{Networking of enterprise creation model}

Enterprise value creation means the organization way of enterprise creating value. Value creased by enterprise is the products provided to customers or total value of service of enterprises in production and management activities, including customer value and enterprise value. Customer value means the balance between profit obtained by customer by buying products and cost (purchasing cost and cost after purchasing) spent by customers, it is the remaining value indication of consumers. Enterprise value means the discounted value of all obtained profit by certain discount rate for enterprises in the future; it is the long-term profit of enterprise. With the changes in enterprise ecological system environment, peoples understanding on enterprise creation model is gradually deepening, they make discussion on relations between technological paradigm transfer and enterprise value network, it is necessary to make reconstruction on enterprise value network, it is formed on the basis of making effective management on enterprise value activity. The start point and end point of value flow is not obviously indicated, organization way of resources and ability is networking, every link of value network can be directly linked, value chain and value network are respectively hierarchical and organization of network.

Table 1 Evolution from value chain to value network

\begin{tabular}{|c|c|c|}
\hline project & value chain & value network \\
\hline environment & static & dynamic \\
\hline focus & detailed industry & $\begin{array}{c}\text { connect with other industry } \\
\text { cooperative fellows }\end{array}$ \\
\hline value creation way & $\begin{array}{l}\text { independent, leverage effect of } \\
\text { self ability }\end{array}$ & $\begin{array}{l}\text { based on leverage effect of } \\
\text { cooperative fellow ability }\end{array}$ \\
\hline relation pattern & small cooperation & stronger cooperation relations \\
\hline $\begin{array}{l}\text { integration of } \\
\text { infrastructure }\end{array}$ & limited integration & total integration \\
\hline $\begin{array}{l}\text { acceleration of } \\
\text { infrastructure }\end{array}$ & cost driving & cost driving \\
\hline profit focus & increase self profit & $\begin{array}{c}\text { increase profit of all cooperated } \\
\text { fellows }\end{array}$ \\
\hline cost focus & consider self profit & consider all cost \\
\hline $\begin{array}{l}\text { leverage effect of } \\
\text { knowledge }\end{array}$ & within enterprise & cross all the nodes \\
\hline resources method & protection & share \\
\hline
\end{tabular}

Based on analysis model of industrial boundary fuzzy, it makes comparative research on background, economic explanation of 2 analysis models: value chain and value network.

The source of value network is customer; it timely conveys customer demand to manufacturers and suppliers through digital information channel, this kind of intimate cooperation relations between enterprise and customer makes customer demand change of value network, circulated and quick order-delivery or supplier/ customer recreation have smart, quick flow and elastic response. 
Table 2 Comparison on analysis model between value chain and value network based on industrial boundary fuzzy

\begin{tabular}{|c|c|c|}
\hline $\begin{array}{c}\text { comparison } \\
\text { element }\end{array}$ & value chain & value network \\
\hline $\begin{array}{c}\text { times } \\
\text { background }\end{array}$ & before 1980s & in the end of 1990s \\
\hline $\begin{array}{c}\text { economic } \\
\text { characteristic }\end{array}$ & resources economy & $\begin{array}{c}\text { knowledge economy, information and } \\
\text { networking }\end{array}$ \\
\hline $\begin{array}{c}\text { definition of } \\
\text { industry } \\
\text { boundary }\end{array}$ & $\begin{array}{c}\text { vertical expansion definition by } \\
\text { business activity }\end{array}$ & $\begin{array}{c}\text { business activity dose not vertically } \\
\text { expand, it is difficult to define towards } \\
\text { other directions }\end{array}$ \\
\hline expansion way & integration within industry & $\begin{array}{c}\text { integration within industry and } \\
\text { cross-industry diversification }\end{array}$ \\
\hline $\begin{array}{c}\text { strategy can be } \\
\text { implemented }\end{array}$ & $\begin{array}{c}\text { group cooperation, strategic } \\
\text { alliance, vertical integration }\end{array}$ & $\begin{array}{c}\text { vertical integration, virtual enterprise, } \\
\text { wide strategic alliance, networking etc }\end{array}$ \\
\hline $\begin{array}{c}\text { economic theory } \\
\text { explanation }\end{array}$ & transaction cost theory & $\begin{array}{c}\text { transtion cost theory, range } \\
\text { economy, network economy, speed } \\
\text { economy }\end{array}$ \\
\hline
\end{tabular}

Table 3 distinction between supply chain and value network

\begin{tabular}{|c|c|c|}
\hline distinction element & supply chain & value network \\
\hline Shape & ordered linear structure & intersected network structure \\
\hline value subject & core enterprise & all members \\
\hline relations to supplier & transaction relations & cooperation relations \\
\hline digitalized result & low information sharing degree & high information sharing degree \\
\hline $\begin{array}{c}\text { key points of } \\
\text { business }\end{array}$ & use enterprise production as core & use customer demand as core \\
\hline $\begin{array}{c}\text { response to customer } \\
\text { demand }\end{array}$ & delay, delivery is not timely & quick response \\
\hline
\end{tabular}

\section{Competition advantage formation mechanism of enterprise value network}

According to change rule and nature of customer value element, in order to increase ability to deal with customer demand changes, member enterprises should make earlier prediction on trend of customer value change. Of which, member enterprises establish customer value element of itself based on actual demand is the most key step, it will continually make test and timely complementary to customer value element established by them, which will make customer value element get gradual improvement, meanwhile it timely eliminates the out-of-dated element from customer value element. Figure 1 is opportunity of value element intersected opportunity of new and old customers in value network member enterprises. The most ideal condition is as follows: customer marginal satisfaction is very small when it reaches s point on satisfaction degree in certain encouragement element; the encouragement effect of encouragement element quickly decreases on customer perception effect and purchasing decision-making. It should use $\mathrm{x}$ to replace $\mathrm{x}_{\mathrm{l}}$ to seek customer element set. Value network is the value creation system by using customer as core, the final aim of the whole organization operation is to meet every requirement of customers, so it should correctly know customer demand in value network model, using idea of customer value as the core to be used as start point and core of all activities for the member enterprises, create customer value, strengthen competition advantage of value network, which has important meanings for survival and development of value network. Customer value creation and competition advantage 
cultivation involves with the whole links of value network, it needs coordinated operation of the whole value network to realize marketing target, and marketing department of member enterprises obviously can not undertake tasks related to marketing.

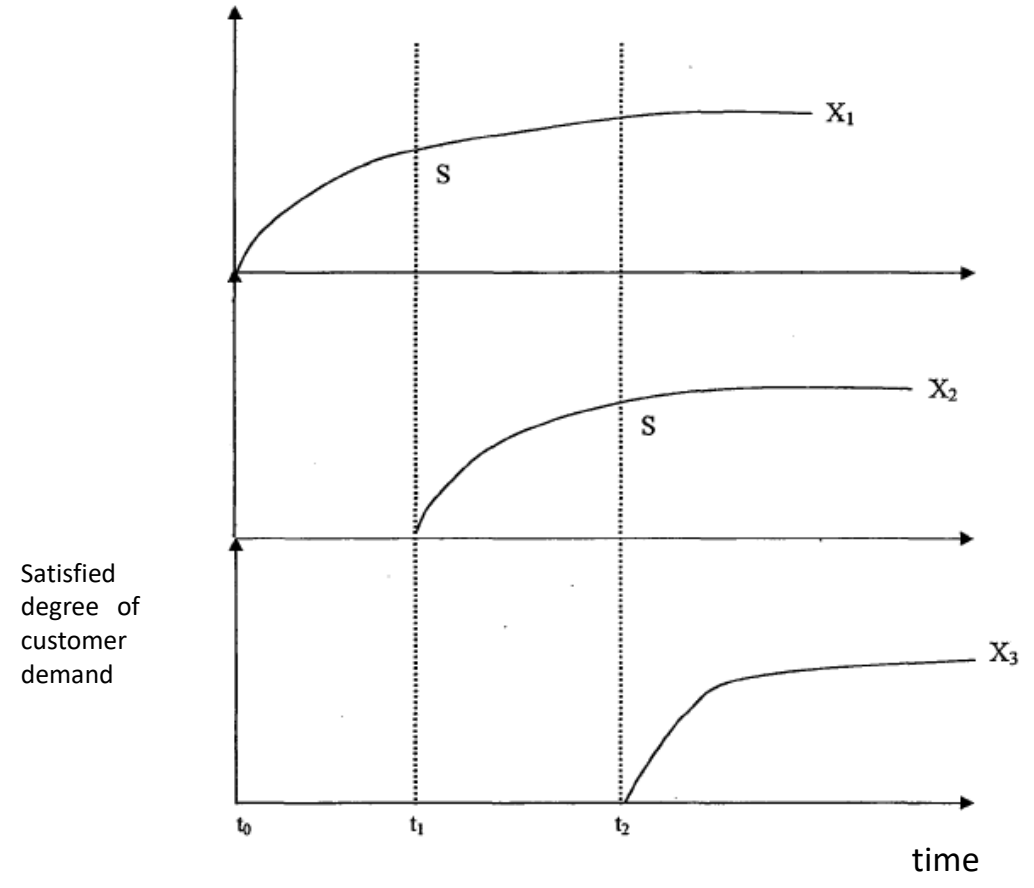

Figure 1 replacement of old and new customer value

Competition based on customer value to demise customer, it can be regarded as competition among member enterprises of value network. As for member enterprises, they create much more value than competitors in value network, only this can make the value of demised customer higher than that of competitors, accordingly their profit will be enhanced and win competition advantage in the competitive game.

\section{Conclusion}

With the approaching of digitalization and network times, which means enterprises will have more advanced and convenient technological measures to use, so they should further consider how to strengthen strategic unification with business fellows so as to convey values by more effective ways. For this, many scholars make discussion and practice on new value chain, which causes birth of value network. Enterprise value network is one kind of new strategic thinking combination, which breaks through linear communication of traditional value chain, value network is one kind of new strategic thinking combination and new business model, its appearance breaks through ordered separation of traditional value chain and mechanical model of linear thinking, which becomes to be the optimal model of obtaining competition advantage in the $21^{\text {st }}$ century. Research on competition advantage formation mechanism of value network is still weak, systematic research outcome is little, research on competition advantage formation mechanism of value network is favorable to explain causes why value network becoming to be new strategic model and enrich research in this field.

\section{References}

[1] Wu Xiaoyun, Zhang Xinyan. Enterprise Ability, Technological Innovation and Value Network Cooperative Innovation and Enterprise Performance [J]. Management Science, 2015, 28(06):12-26.

[2] Wang Tingting, Kang Rong. Research on Competition Advantage Formation Mechanism and Locking Effect of Enterprise Value Network in New Economic Times [J]. Management Journal, 2016, 29(03):35-40. 
[3] Meng Dan. Competition Advantage, Transnational Merge and Correlation of Global Value Network [J]. Reform, 2013(01):125-132.

[4] Yang Guizhong, Zhong Min. Research Overview on Global Value Network [J]. Enterprise Guide Report, 2013(01):1-3.

[5] Zhang Tao, Wang Zongshui, Zhao Hong. Research on Value Network Subject Identification of Xinjianig Agricultural Product Based on Social Network Analysis[J]. Science Promote Development, 2017, 13(05):341-348. 